\title{
Three new species of Cycas (Cycadaceae) from the Northern Territory, Australia
}

\author{
K.D. Hill
}

\begin{abstract}
Hill, K.D. (National Herbarium of New South Wales, Royal Botanic Gardens, Mrs Macquaries Road, Sydney NSW 2000 Australia). New species of Cycas (Cycadaceae) from the Northern Territory. Telopea 5(4): 693-701. Three new species of Cycas endemic to the Northern Territory are described (Cycas arnhemica, C. orientis, C. canalis), one with two subspecies (C. canalis subsp. carinata). All taxa are illustrated, and affinities are discussed.
\end{abstract}

\section{Introduction}

Three new species are described as part of an overall review of the genus Cycas in Australia. Two other new species occurring in the Northern Territory are to be described by other workers. The names below are becoming current in horticultural circles, and formal validation is desirable at this stage in order to establish nomenclature and to provide conservation authorities with legitimate names for licensing and management purposes. This precedes a complete review of the Australian species currently in preparation.

Cycas arnhemica K.D. Hill, sp. nov.

Inter species australienses combinatione characterum sequentium distinguitur: frondes plani atrovirides, petioli breves, pinnae carinatae leviter recurvatae.

TYPE: Nortiern Territory: Goyder River crossing, J.R. Maconochie 1477, 16 Jun 1977 (holo NSW; iso DNA)

Stem to $4 \mathrm{~m}$ tall, rarely to $7 \mathrm{~m}, 12-19 \mathrm{~cm}$ diam. Leaves $65-110 \mathrm{~cm}$ long, flat in section (opposing pinnae inserted at $150-180^{\circ}$ on rachis), with $120-270$ pinnae; petiole loosely white-tomentose, 9-36 cm long; median pinnae at $45-70^{\circ}$ to rachis, often falcate, 50$170 \mathrm{~mm}$ long, 5.0-7.5 mm wide, often loosely white-tomentose beneath, sub-glossy slightly bluish deep green, more or less keeled in section with slightly recurved margins, decurrent for $2.5-4.0 \mathrm{~mm}$, narrowed to $4.0-5.0 \mathrm{~mm}$ at base $(65-90 \%$ of maximum width), spaced at 7-13 $\mathrm{mm}$ on rachis, apex attenuate; midrib not or slightly raised above, prominent below. New growth densely tomentose with white and few orange trichomes. Cataphylls densely orange-tomentose, 3-6 cm long, fleshy. Microsporangiate cones elongate-ovoid, $18-30 \mathrm{~cm}$ long, $6.5-8 \mathrm{~cm}$ diam. Microsporophyll lamina 15-20 mm long, 11-13 $\mathrm{mm}$ wide; sterile apex 6-8 $\mathrm{mm}$ long, not recurved, apical spine slender, sharply upturned, 11-22 mm long. Megasporophylls $16-20 \mathrm{~cm}$ long, grey- and orange-tomentose, with 1-4 ovules, sterile apex 40-70 $\mathrm{mm}$ long, 15$22 \mathrm{~mm}$ wide, narrowly triangular, regularly dentate, with 10-18 lateral teeth, apical spine $8-25 \mathrm{~mm}$ long, lateral teeth $2-5 \mathrm{~mm}$ long. Seeds flattened-ovoid, green maturing to orange, not pruinose, $28-33 \mathrm{~mm}$ long, $27-30 \mathrm{~mm}$ diam.; sarcotesta $2.5-4 \mathrm{~mm}$ thick. Fig. 1.

Distinguished by the robust habit and the flat (not keeled), dark green leaves with relatively short petioles and well-spaced, keeled pinnae with somewhat recurved 
margins. The pinnae are also distinctly angled towards the leaf apex, whereas those of a closely related undescribed species from Groote Eylandt are more or less perpendicular to the rachis. Leaf bases and trunks retain a dense dark brown tomentum that is not evident in other taxa from Arnhem Land, and the apical spine of the microsporophylls is more attenuate. Cataphylls are also shorter, softer and fleshier.

Locally abundant on deep white to yellow sands over laterites, in Eucalyptus tetrodontaE. miniata dominated savanna forests around the Goyder River (Fig. 2).

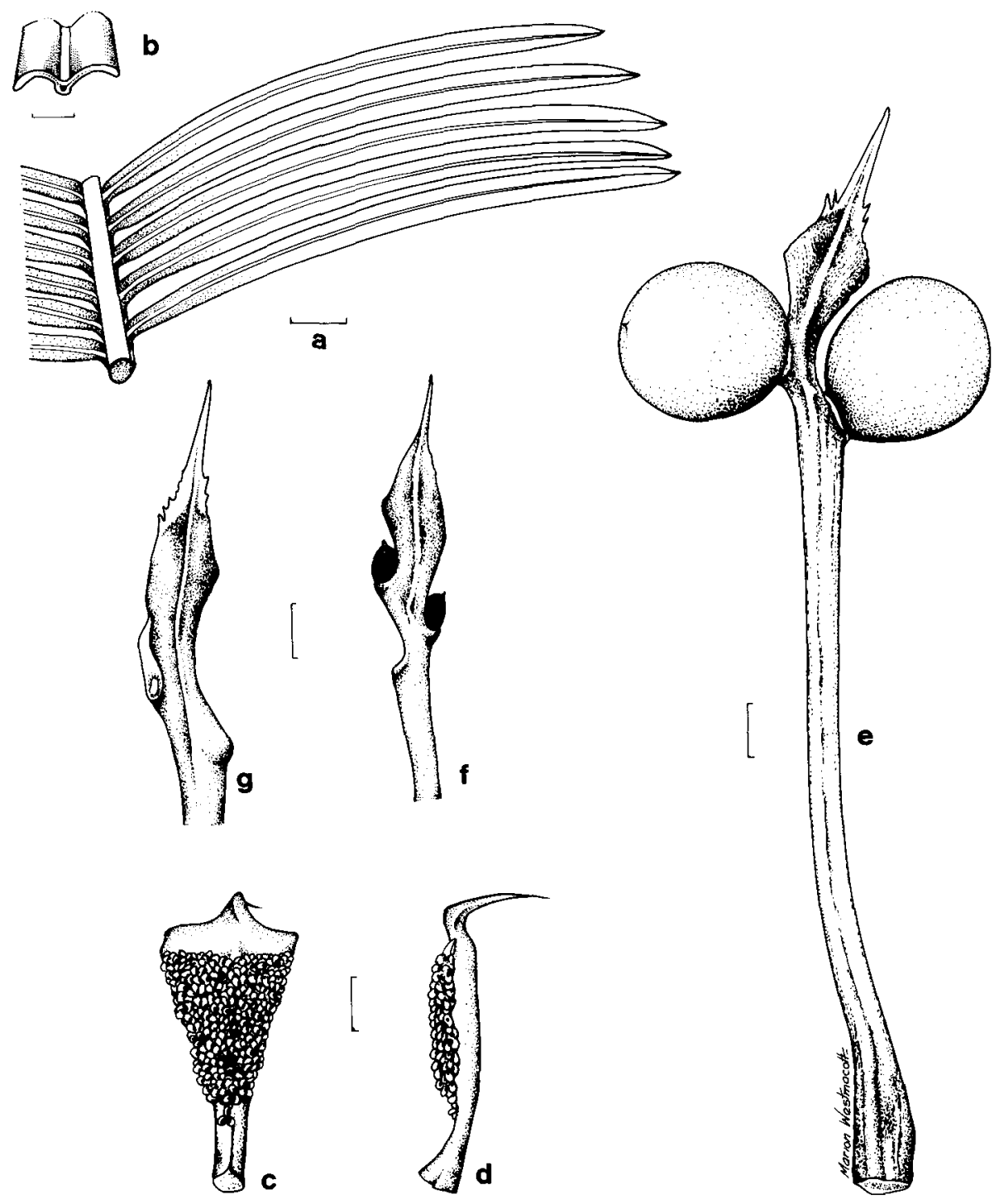

Fig. 1. Cycas arnhemica. a, part of leaf; $\mathbf{b}$, section of pinna; $\mathbf{c}, \mathbf{d}$, microsporophyll; e, megasporophyll with seed and stipe; $\mathbf{f}, \mathbf{g}$, tips of megasporophylls $(\mathbf{a}, \mathbf{b}, \mathbf{c}$, d, from Hill 3920, e from Maconochie 1477, f from Hill 3920a, $\mathbf{g}$ from Hill 3920b). Scale bar: $\mathbf{a}, \mathbf{e}, \mathbf{f}, \mathbf{g}=1 \mathrm{~cm} ; \mathbf{b}=2 \mathrm{~mm}$; , $\mathrm{d}=5 \mathrm{~mm}$. 
Plants from further north-east (around Badalngarrmirri Creek) show glossier, paler green leaves, pinnae with a more prominent midrib on the upper surface, and a more slender habit, suggesting some intergradation with $C$. orientis. Those from further north-west, between the Blyth and Goyder Rivers, show smaller leaves with narrower and more crowded pinnae, indicating intergradation with populations of another undescribed species that occurs on Groote Eylandt and on the north coast of Arnhem Land.

CONSERVATION STATUS: Locally abundant and fairly widespread, not considered to be at risk. Although not reserved, the extreme abundance of this species would buffer it from any threat in the medium term. Almost all populations are on Aboriginal land, and conservation issues on such land are yet to be fully addressed. The inhibition of reproduction by too-frequent fire is one such issue.

The epithet refers to the occurrence of this species more or less in the centre of Arnhem Land.

Selected SPECIMENS (from 21 examined): NoRTHERN TERRIToRy: Darwin \& Gulf: $13.2 \mathrm{~km}$ E of Ramangining turnoff on Gove road, Hill 3919 E Stanberg, 25 Aug 1991 (NSW, CANB); $29.5 \mathrm{~km}$ E of Ramangining turnoff on Gove road, Hill 3920 \& Stanberg, 25 Aug 1991 (NSW); $43.5 \mathrm{~km}$ NNE of Goyder River crossing, Maconochie 1626, 22 Jun 1972 (DNA, AD); Goyder River crossing, Maconochie 1478, 16 Jun 1977 (DNA); 25.5 km S of Goyder River crossing, Maconochie 1466, 16 Jun 1977 (DNA, AD).

C. arnhemica - C. species northern Arnhem Land probable intergrade (1 specimen) NORTHERN TERRITORY: Darwin \& Gulf: 43.8 miles [c. $70 \mathrm{~km}$ ] from Gove - Bulman Junction road on Maningrida road, Meehan 54, 9 Sep 1972 (DNA).

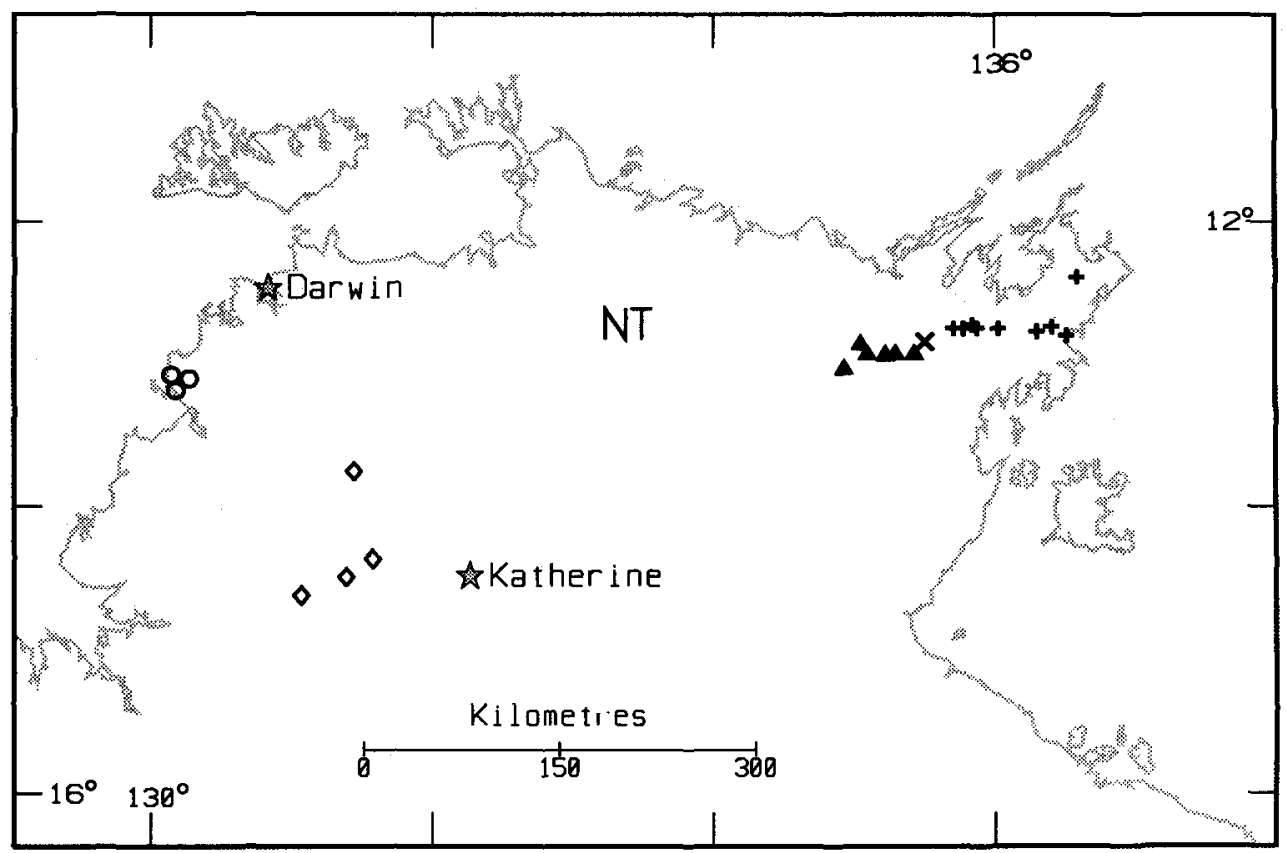

Fig. 2. Distribution of Cycas arnhemica (triangle), C. orientis (plus), C. arnhemica-orientis intergrades (cross), C. canalis subsp. canalis (circle), C. canalis subsp. carinata (diamond). 


\section{C. arnhemica $-\mathrm{C}$. orientis probable intergrades ( 3 specimens)}

NORTHERN TERRTTORY: Darwin \& Gulf: $64.9 \mathrm{~km}$ E of Ramangining turnoff on Gove road (Badalngarrmirri Creek), Hill 3930 \& Stanberg, 25 Aug 1991 (NSW); Arnhem Land, Maconochie 1510, 17 Jun 1972 (DNA, AK); c. 5 km NE of McLaren River crossing, Maconochie 1622, 23 June 1972 (DNA, CANB, K).

\section{Cycas orientis K.D. Hill, sp. nov.}

Inter species australienses combinatione characterum sequentium distinguitur: frondes prasinae, petioli longiores, pinnae planae marginibus non recurvatis, costae infra prominentiores.

Type: Northern Territory: $48.9 \mathrm{~km}$ E of Badalngarrmirri Creek, K.D. Hill $3936 \mathcal{E}$ L. Stanberg, 26 Aug 1991 (holo NSW; iso CANB, DNA).

Stem to $4 \mathrm{~m}$ tall, rarely to $7 \mathrm{~m}, 8-14 \mathrm{~cm}$ diam. Leaves $55-125 \mathrm{~cm}$ long, flat in section (opposing pinnae inserted at $160-180^{\circ}$ on rachis), with 130-180 pinnae; petiole usually glabrous, $17-35$, rarely to $52 \mathrm{~cm}$ long; median pinnae at $50-80^{\circ}$ to rachis, $60-160$ $\mathrm{mm}$ long, $4.5-7.0 \mathrm{~mm}$ wide, glabrous, glossy mid-green, flat in section with flat margins, discolorous, decurrent for $2.0-3.5 \mathrm{~mm}$, narrowed to $3.0-5.0 \mathrm{~mm}$ at base $(50-$ $80 \%$ of maximum width), spaced at $5-10 \mathrm{~mm}$ on rachis, apex attenuate; midrib slightly to moderately raised above, prominent below. New growth densely tomentose with white and few orange trichomes. Cataphylls densely orange-tomentose, $4-8 \mathrm{~cm}$ long, hard and pungent. Microsporangiate cones ovoid, c. $20 \mathrm{~cm}$ long, c. $8 \mathrm{~cm}$ diam. Microsporophyll lamina c. $20 \mathrm{~mm}$ long, c. $14 \mathrm{~mm}$ wide; apical spine slender, sharply upturned, geniculate, flat a pex c. $6 \mathrm{~mm}$ long, upturned spine c. $10 \mathrm{~mm}$ long. Megasporophylls $14-24 \mathrm{~cm}$ long, grey and orange tomentose, with 1-4 ovules, sterile apex 40$90 \mathrm{~mm}$ long, 15-25 mm wide, narrowly triangular, regularly dentate, with 10-16 lateral teeth, apical spine 14-63 mm long, lateral teeth 4-8 mm long. Seeds flattenedovoid, orange, slightly pruinose, 25-36 mm long, 25-34 mm diam.; sarcotesta 3-4 mm thick. Fig. 3.

Distinguished by the mid-green leaves with relatively long petioles and flat pinnae with the midrib more prominent beneath. Leaves in general resemble those of C. armstrongii, which differs in having the midrib equally prominent on both sides of the pinnae. C. armstrongii also has a generally smaller stature with more slender stems and shorter leaves with shorter petioles.

Locally abundant on deep white to yellow sands over laterites, mainly in savanna forests dominated by Eucalyptus tetrodonta and E. miniata, but occurring in most nonswampy sites, widespread in eastern Arnhem Land (Fig. 2). Intergradation occurs with $C$. arnhemica where the ranges adjoin (representative specimens cited under C. arnhemica).

CONSERVATION STATUS: Locally abundant and very widespread, in remote country, not considered to be at risk. The entire occurrence is within Aboriginal land, and the comments above for $C$. arnhemica apply.

The epithet is from the Latin orientis, of the east, referring to the occurrence in the east of Arnhem Land.

SElected specimens (from 15 examined): Northern Territory: Darwin \& Gulf: $5.9 \mathrm{~km}$ SW of Telecom repeater tower $\left(12^{\circ} 44^{\prime} \mathrm{S} 136^{\circ} 23^{\prime} \mathrm{E}\right)$, Hill 3959 \& Stanberg, 27 Aug 1991 (NSW); $3.1 \mathrm{~km} \mathrm{E}$ of Dhalinbuy turnoff, Hill $3949 \mathcal{E}$ Stanberg, 27 Aug 1991 (NSW); Buckingham River, 8 miles [12 $\mathrm{km}$ ] from mouth, McKean B 977, 21 Feb 1973 (DNA); $40 \mathrm{~km}$ NE of BHP airstrip, Arnhem Land, Maconochie 1506, 17 Jun 1972 (DNA, AD); Arnhem Land (12 50'S 135 15'E), Maconochie 1568, 24 June 1972 (DNA); 19.3 km E of Gan Gan turnoff, Hill 3943 \& Stanberg, 26 Aug 1991 (NSW, CANB); 6.5 km E of Lake Evella turnoff, Maconochie 1514, 18 Jun 1972 (DNA); Caledon Bay, Maconochie 1556, 22 Jun 1972 (DNA, BRI); 58 km NE of BHP airstrip, Arnhem Land, Maconochie 1511, 18 Jun 1972 (DNA). 


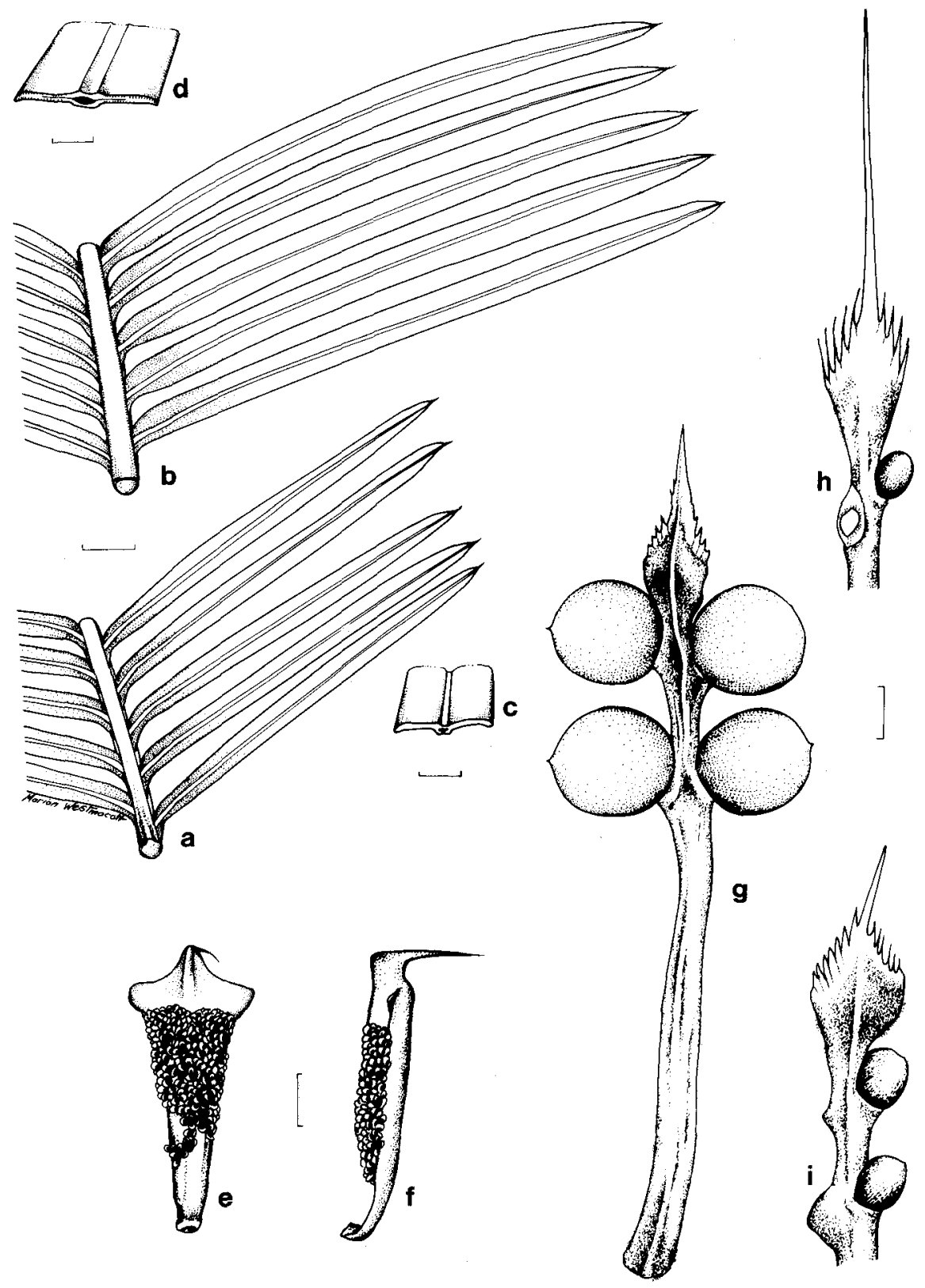

Fig. 3. C. orientis. $\mathbf{a}, \mathbf{b}$, parts of leaves; $\mathbf{c}, \mathbf{d}$, sections of pinnae; $\mathbf{e}, \mathbf{f}$, microsporophyll; $\mathbf{g}$, megasporophyll with seed and stipe; $\mathbf{h}$, $\mathbf{i}$, tip of megasporophyll $(\mathbf{a}, \mathbf{c}, \mathbf{h}$, $\mathbf{i}$ from Hill $3949 \mathbf{b}$, $\mathbf{d}$ from Maconochie 1568, e, f, from Hill 3943a, g from Hill 3943)bar: a, b, g, h, i $=1 \mathrm{~cm} ; \mathbf{c}, \mathbf{d}=2 \mathrm{~mm}$; , $\mathbf{f}=5 \mathrm{~mm}$. 


\section{Cycas canalis K.D. Hill, sp. nov.}

Inter species australienses combinatione characterum sequentium distinguitur: frondes juniores pruinosae maturitate viridae, pinnae planae longiores, cataphylla longiora.

TYPE: NORTHERn TERRITORY: $31.4 \mathrm{~km}$ from Labelle Downs homestead on track to Channel Point, K.D. Hill $4034 \mathcal{E}$ L. Stanberg, 08 Sep 1991 (holo NSW; iso CANB, DNA)

Stem to $3 \mathrm{~m}$ tall, rarely to $5 \mathrm{~m}, 7-14 \mathrm{~cm}$ diam. Leaves $60-105 \mathrm{~cm}$ long, flat or slightly keeled in section (opposing pinnae inserted at $130-180^{\circ}$ on rachis), with $100-170$ pinnae, usually terminated by a spine; petiole glabrous or loosely orange-tomentose, usually spinescent throughout, $15-25 \mathrm{~cm}$ long; median pinnae at $40-90^{\circ}$ to rachis, 100-205 mm long, 4.5-8.0 mm wide, glabrous, strongly glaucous when new, becoming glossy mid-green, to deep green, flat in section, decurrent for 1-2 mm, narrowed to $3.0-5.0 \mathrm{~mm}$ at base (40-60\% of maximum width), usually not crowded or overlapping on rachis, apex attenuate; midrib slightly raised above, prominent below. New growth densely loosely tomentose with orange and grey trichomes. Cataphylls densely tomentose with thick orange woolly trichomes, $7-9 \mathrm{~cm}$ long. Microsporangiate cones orange, ovoid, 15-22 cm long, 8-12 cm diam. Microsporophyll lamina 28-32 mm long, 15-23 mm wide; sterile apex 8-14 mm long, apical spine slender, sharply upturned, 11-18 mm long. Megasporophylls 16-25 cm long, grey- and orange-tomentose, with 2-4 ovules, sterile apex $40-60 \mathrm{~mm}$ long, 22-32 mm wide, triangular, regularly dentate, with 12-20 lateral teeth, apical spine $10-30 \mathrm{~mm}$ long, lateral teeth 2 $6 \mathrm{~mm}$ long. Seeds flattened-ovoid, green maturing to orange, not pruinose, 34-40 $\mathrm{mm}$ long, 30-36 mm diam.; sarcotesta 2-4 mm thick. Fig. 4.

Distinguished by the strongly glaucous new growth, the long pinnae with flat margins and midrib more prominent below, and the thickly woolly and prominent cataphylls.

Widespread and locally abundant, on a variety of well-drained soil types, usually on lateritic soil profiles in open forest or woodland with Eucalyptus miniata. Known from near-coastal sites at Channel Point, and an apparently disjunct inland occurrence between Douglas Hot Springs and Dorisvale (Fig. 2). The inland population differs in the longer leaves, petioles and pinnae, and the keeled leaves, and the lower rachis-topinna angle, and is here recognised as a subspecies.

The epithet is from the Latin canalis, a canal or channel, in reference to the occurrence of this species at Channel Point.

\section{Key to the subspecies}

Pinna-to-rachis angle more than $60^{\circ}$, leaves flat

A. subsp. canalis

Pinna-to-rachis angle less than $60^{\circ}$, leaves openly keeled

B. subsp. carinata

\section{A. Cycas canalis K.D. Hill subsp. canalis}

Stem to $3 \mathrm{~m}$ tall, rarely to $5 \mathrm{~m}, 7-13 \mathrm{~cm}$ diam. Leaves $60-90 \mathrm{~cm}$ long, flat in section (opposing pinnae inserted at about $180^{\circ}$ on rachis), with 110-160 pinnae; petiole 15$25 \mathrm{~cm}$ long; median pinnae at $50-90^{\circ}$ to rachis, $100-190 \mathrm{~mm}$ long, $4.5-7.5 \mathrm{~mm}$ wide. Microsporangiate cones 15-22 cm long, 8-11 cm diam. Microsporophyll lamina 28-32 $\mathrm{mm}$ long, 17-23 mm wide; sterile apex 8-14 mm long, not recurved, apical spine 14$18 \mathrm{~mm}$ long. Megasporophylls $16-22 \mathrm{~cm}$ long, with 2-4 ovules, sterile apex $40-60 \mathrm{~mm}$ long, 22-32 mm wide. Fig. 4.

Distinguished from the following subspecies by the somewhat smaller leaves with smaller pinnae, the non-keeled leaves, and the high pinna-to-rachis angle. 


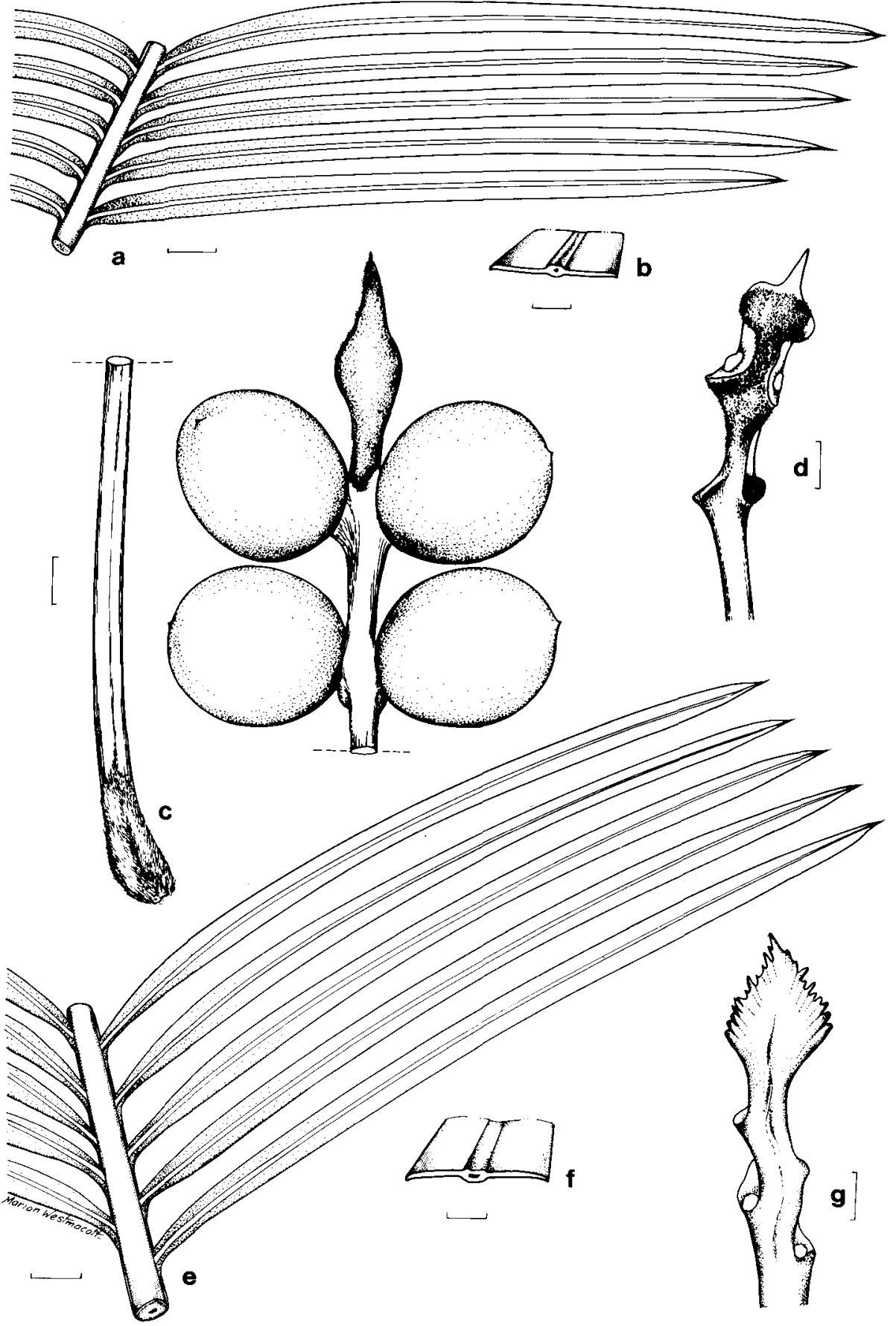

Fig. 4. C. canalis subsp. canalis a, part of leaf; $b$, section of pinna; $c$, megasporophyll with seed and stipe; $\mathbf{d}$, tip of megasporophyll (probably reduced by insect damage during development). C. canalis subsp. carinata. e, part of leaf. $\mathbf{f}$, section of pinna. $\mathbf{g}$, tip of megasporophyll. (a, b, d from Hill 4038, c from Hill 4034, e, f, $\mathbf{g}$ from Hill 4063). Scale bar: a, c, d, e, $\mathbf{g}=1 \mathrm{~cm} ; \mathbf{b}, \mathbf{f}=2 \mathrm{~mm}$. 
Locally abundant in near-coastal situations, on well-drained soil in Eucalyptus miniata forest. Known from around Channel Point, to the north of the mouth of the Daly River (Fig. 2), and reported from coastal country south of the mouth of the Daly River (no confirmatory specimens are known).

CONSERVATION STATUS: Locally extremely abundant, not considered to be at risk. Although not well reserved, the extreme abundance of this species would buffer it from any threat in the medium term. However, frequent fire effectively blocks reproduction, and uncontrolled residential and tourist development could potentially destroy large proportions of the population.

Selected specimens (from 6 examined): NoRTHern Territory: Darwin \& Gulf: $54.6 \mathrm{~km}$ from Labelle Downs homestead on track to Channel Point, Hill 4043 \& Stanberg, 08 Sep 1991 (NSW); $50.1 \mathrm{~km}$ from Labelle Downs homestead on track to Channel Point, Hill 4038 \& Stanberg, 08 Sep 1991 (NSW); $31.4 \mathrm{~km}$ from Labelle Downs homestead on track to Channel Point, Hill 4034, 4035 \& Stanberg, 08 Sep 1991 (NSW, CANB).

\section{B. Cycas canalis K.D. Hill subsp. carinata K.D. Hill, subsp. nov.}

$\mathrm{Ab}$ subspecie canali frondibus, petiolis pinnisque longioribus, frondibus carinatis, pinnis sub angulo $50^{\circ}$ patentibus distinguitur.

TYPE: NoRTHERN TERRTTORY: $90.0 \mathrm{~km}$ from Stuart Highway on Dorisvale road, K.D. Hill $4063 \mathcal{E}$ L. Stanberg, 11 Sep 1991 (NSW).

Stem to $2 \mathrm{~m}$ tall, rarely to $5 \mathrm{~m}, 8-14 \mathrm{~cm}$ diam. Leaves $70-105 \mathrm{~cm}$ long, somewhat keeled in section (opposing pinnae inserted at $130-170^{\circ}$ on rachis), with $100-170$ pinnae; petiole $15-25 \mathrm{~cm}$ long; median pinnae at $40-50^{\circ}$ to rachis, $125-205 \mathrm{~mm}$ long, $4.5-8.0 \mathrm{~mm}$ wide. Microsporangiate $15-20 \mathrm{~cm}$ long, $11-12 \mathrm{~cm}$ diam. Microsporophyll lamina c. $28 \mathrm{~mm}$ long, c. $15 \mathrm{~mm}$ wide; sterile apex c. $12 \mathrm{~mm}$ long, recurved, apical spine stout, sharply upturned, c. $11 \mathrm{~mm}$ long. Megasporophylls $16-25 \mathrm{~cm}$ long, with 2 ovules, sterile apex $45-55 \mathrm{~mm}$ long, 22-25 mm wide. Fig. 4.

Distinguished from subsp. canalis by the longer leaves, petioles and pinnae, and the keeled leaves, and the low rachis-to-pinna angle (less than $50^{\circ}$ ).

A sporadic and scattered taxon over a considerable area, usually on lateritic soil profiles in open forest or woodland with Eucalyptus miniata. Known from around Douglas Hot Springs, south to Dorisvale and some distance east and west of there (Fig. 2).

COnSERVATION Status: Widespread, not considered to be at risk.

The epithet is from the Latin carinatus, keeled, in reference to the keeled leaves.

SPeCimens eXamined: NoRthern Territory: Darwin \& Gulf: road to Douglas Hot Springs Reserve, Hill 4505 \& Perner, 09 Sep 1993 (NSW); $63.4 \mathrm{~km}$ from Stuart Highway on Dorisvale road, Hill $4061 \&$ Stanberg, 11 Sep 1991 (NSW, CANB); $17.4 \mathrm{~km}$ from road junction $36.8 \mathrm{~km}$ W of Dorisvale, on track Daly River Aboriginal land, Hill 4067 \& Stanberg, 11 Sep 1991 (NSW); $15 \mathrm{~km}$ from road junction $36.8 \mathrm{~km} \mathrm{~W}$ of Dorisvale, on track to Daly River Aboriginal land, Hill $4064 \mathcal{E}$ Stanberg, 11 Sep 1991 (NSW, CANB). 


\section{Acknowledgments}

Peter Wilson is thanked for assistance with the Latin diagnoses of new taxa. Cycad enthusiasts who have contributed materially with their field knowledge have been Monty Anderson and Craig Walker of Darwin, and Joe Perner of Katherine. Leonie Stanberg has provided valuable technical assistance in the field and laboratory. Marion Westmacott is thanked for the illustrations. The directors of the herbaria DNA and BRI are thanked for the loan of important specimens, the former also most importantly for access to notes and collections left by the late John Maconochie.

Manuscript received 4 November 1993

Manuscript accepted 25 January 1994 